Papers and Proceedings of the Royal Society of Tasmania, Volume 115, 1981

(ms. received 27.11 .1980$)$

\title{
A SHORT POLLEN DIAGRAM FROM CROWN LAGOON IN THE MIDLANDS OF TASMANIA
}

by W.R. Sigleo and E.A. Colhoun

Department of the Interior, Geological Survey, Reston, Virginia and University of Tasmania.

(with one table and three text-figures)

\section{ABSTRACT}

SIGLEO, W.R. and COLHOUN, E.A., 1981 (30 ix): A short pollen diagram from Crown Lagoon

in the Midiands of Tasmania. Pap. Proc. R. Soc. Tasm., 115, 181-188 (with three

figures).https://doi.org/10.26749/rstpp.115.181 ISSN 0080-4703. Department of the

Interior, Geological Survey, Reston, Vixginia, U.S.A. and University of Tasmania,

Hobart, Tasmania, Australia.

Pollen analysis of a $2 \mathrm{~m}$ core from the floor of Crown Lagoon in the Midlands of Tasmania indicates that the vegetation varied from grassy woodland through grass land to grassy woodland and grassy open-forest during late Pleistocene and Holocene times. It is suggested that these variations represent changes of climate from moister to colder and drier conditions during the later part of the Last Glacial stage (25 $000-10$ 000 BP) with a return to moister conditions in the Holocene. The core is undated.

\section{INTRODUCTION}

During a recent investigation of the stratigraphy of the aeolian sediments that compose a lunette and the clays that floor the adjacent dry lake at Crown Lagoon near Lemont (lat. $42^{\circ} 17^{\prime} \mathrm{S}$; long. $147^{\circ} 38^{\prime} \mathrm{E}$ ) in the Midlands of Tasmania (fig. 1) a short core was taken for pollen analysis. The core from the Upper Unit of lacustrine clays (Sigleo 1979; Sigleo and Colhoun 1981) was obtained by the Tasmanian Department of Mines whose drilling and seismic work showed that the following stratigraphy occurred beneath the core site located at the obtuse angle on the section line A-B (fig. 2):

0-0.45 m Very dark grading downwards to dark greyish-brown organic-rich silty clay with a distinct thin horizon of clayey fine quartz sand at $0.45 \mathrm{~m}$.

0.45-2.05 m Olive-coloured silty clay with 5-10 per cent of very fine quartz sand.

$2.05-15 \mathrm{~m}$ Greenish grey to greenish black deeply weathered basalt.

$15+\mathrm{m} \quad$ Unweathered Tertiary basalt.

This brief paper records the pollen obtained from the core and makes an interpretation of the vegetation and palaeoclimatic history of the area after some general considerations on the present environment and dating of the sediments.

The floor of Crown Lagoon occurs at $375 \mathrm{~m}$ on a plateau surface of between 370 and $450 \mathrm{~m}$ above sea-level on the eastern boundary of the Midland Graben (350-500 $\mathrm{m}$ ) with the Eastern Highlands $(600-800 \mathrm{~m})$ of Tasmania. The area has cool winters $\left(5^{\circ} \mathrm{C}\right)$ and warm summers $\left(15^{\circ} \mathrm{C}\right)$, and is sub-humid. Precipitation increases slightly eastwards from $400-$ $500 \mathrm{~mm}$ in the rain-shadowed Midlands to $600-700 \mathrm{~mm}$ on the Eastern Highlands. West of the Midlands the steep Jurassic dolerite escarpment of the southern part of the Western Tiers rises to 900-1100 $\mathrm{m}$ and forms the eastern margin of the Central Plateau which, though cooler, is also a relatively dry region with precipitation values of approximately $700 \mathrm{~mm}$. 


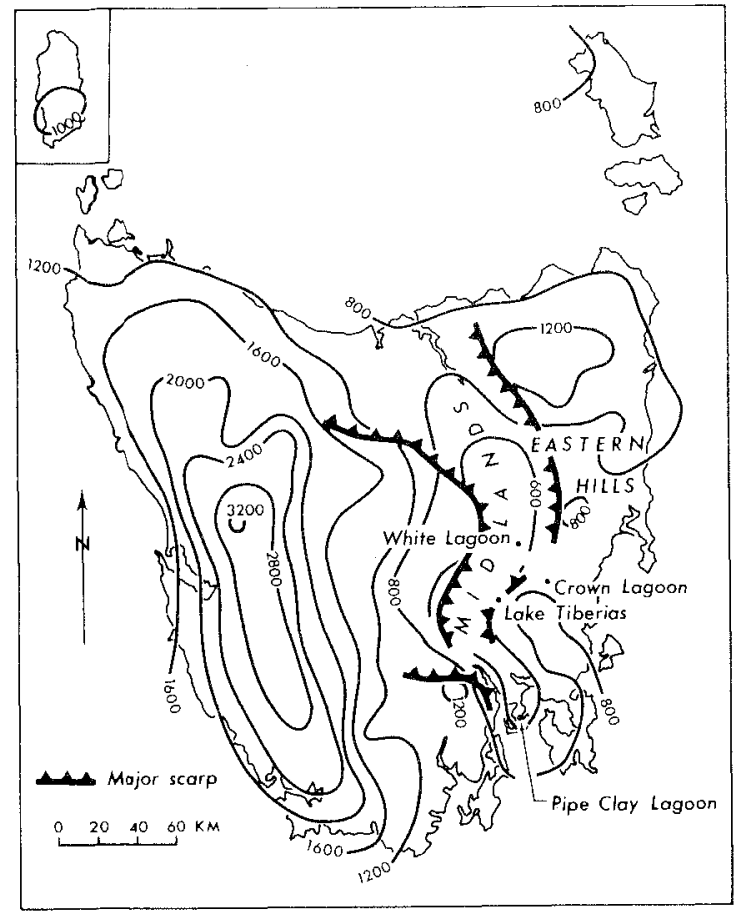

FIG. 1 - Topography and precipitation $(\mathrm{mm})$ in Tasmania.

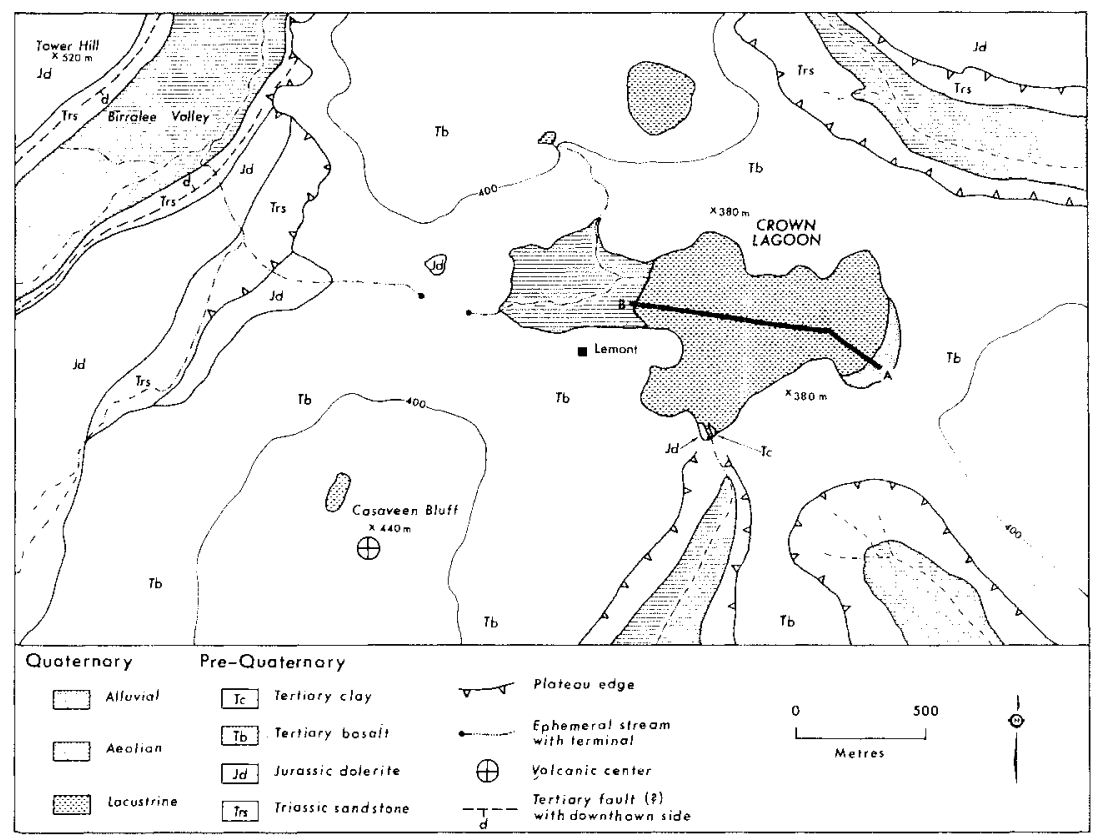

FIG. 2 - Crown Lagoon 
There is a broad correlation between the vegetation and climate of these three north-south trending zones which were, prior to the advent of agriculture and lumbering, predominantly occupied by grassy open-forests and woodlands on the Central plateau, tall open-forests on the scarp of the Western Tiers, grassy woodlands in the Midlands and openforests with shrub understoreys on adjacent parts of the Eastern Highlands (Specht 1970). On the dolerite escarpment Eucalyptus delegatensis is the dominant tree and broadleaf shrubs form an understorey. On the plateau a sequence related to drainage occurs which varies Erom $E$. rodwayi in poorly-drained depressions through $E$. pauciflora and $E$. dalrympleana with a grass ground layer on gentle slopes to $E$. delegatensis with sclcrophyll shrubs on the steepest slopes. The grassy woodlands of the Midlands were dominated by $E$. ovata and $E$. pauciflora with a ground layer of tussock grasses on lower, less well-drained sites, and by $E$. viminalis and $E$. amygdalina on higher, drier ridge sites. E. delegatensis, E. viminalis and $E$. amygdatina are the most important species of the open-forests on the adjacent part of the Eastern Highlands (Kirkpatrick 1981).

Insufficient organic material was obtained from the core at Crown Lagoon to provide ${ }^{14} \mathrm{C}$ assays to date the lake clays and the vegetation changes as inferred from the pollen content. Although undated it is suggested that the lithological boundary at $0.45 \mathrm{~m}$ approximately divides the pleistocene and Holocene deposits.

\section{POLLEN ANALYSIS}

Pollen samples were taken at $0.1 \mathrm{~m}$ intervals and were processed using HF digestion and acetolysis (Mehringer 1967) as required for sediments likely to have low pollen concentrations. The pollen taxa were identified and counted at $600 x$ using reference materials supplied by the Botany Department of the University of Tasmania and standard keys. The method of counting employed the double fixed sum procedure (Adam 1967). The first sum of 200 grains included all pollen taxa. To obtain the second sum the values for aquatic taxa were subtracted from the first sum and an additional sum of 200 grains was counted for all non aquatic types. Spores of pteridophytes were excluded. The results are shown separately on the relative pollen diagram of figure 3 as infilled and open curves respectively for individual taxa. The nomenclature follows Curtis and Morris (1975) and Curtis (1963, 1967).

\section{Modern Pollen}

For the purposes of interpretation of the relationship between the pollen and vegetation two modern surface samples were taken from within and adjacent to a small undrained marsh $600 \mathrm{~m}$ northeast of the lagoon. Each surface sample integrates 36 sub-samples that were collected from a $50 \mathrm{~m}^{2}$ area at $10 \mathrm{~m}$ grid intervals.

Examination of Table 1 suggests that in the grassy woodlands, Eucalyptus pollen is overrepresented by a factor of approximately 2 while grass is underrepresented by a factor of 0.6 . Pollen of Compositae is grossly overrepresented but the absence of Compositae from the sampled area is not typical for the whole area where both native and introduced Compositae are widespread. Cyperaceae pollen is underrepresented by a factor of 0.5 . Phyllocladus aspleniifolius (1\%) is the only long distance indigenous component presently reaching the site and this pollen is windborne a minimum distance of $40 \mathrm{~km}$ from the Central plateau to the west.

In the marsh habitat, which probably most closely resembles the conditions at Crown Lagoon prior to its artificial draining at the end of last century, Myriophyzlum pollen is underrepresented by a factor of 0.65 while the herbs Pratia and Vizzarsia are not represented by pollen. Pollen of Cyperaceae exceeds the presence of Eleocharis by a factor of 3.8 and is probably mainly of local habitat origin. In addition, pollen of Myrtaceae, Gramineae and Compositae is recorded in substantial quantities in the marsh assemblage and clearly represents the main components of the local dryland vegetation. As in the grassy woodland, the Myrtaceae pollen ( $=$ Eucalyptus) exceeds the percentage Eucalyptus cover by a factor of between 1.3 and 3 to 1 , and while the Gramineae pollen overrepresents the local marsh grass it underrepresents the regional grass cover by a factor of 0.25 to 0.35 . 
TABLE 1

MODERN PLANT SPECIES AND POLLEN ASSEMBLAGES FROM SAMPLE SITES ADJACENT TO CROWN LAGOON

Species

Eucaluptus ovata
Eucalyptus pauciflora
Banksia marginata
Coprosma quadrifida
Poa spp.
Danthonia spp.
Themeda australis
Convolvulus sp.
CYPERACEAE
Rumex acetosellat
Plantago majort
Oxalis corniculata
Acaena echinata
Geranizm sp.
Anagalis arvensist

Pollen taxa only:

Acacia

Bursaria spinosa

Casuarina

Dodonaea

Piriust

Phyzloctadus aspleniifolius

CUPRESSACEAE? $\uparrow$

COMPOS ITAE

Unknowns

\section{Muriophyzzum}

Pratia spp.

Vizzarsia exaltata

Eleocharis sp.

Hydrocotyze sp.

GRAMINEAE

Triglochin procera

Utriaularia sp.

Lepidosperma sp.

Juncus sp.

Pollen taxa only:

Myrtaceae

Casuarina

CUPRESSACEAE? $\dagger$

Goodenia

COMPOSITAET (partly)

CHENOPOD I ACEAE/AMARANTHACEAE

Unknowns

$\dagger$ introduced species

\section{Relative}

Cover, \%

First Sum

Pollen, $\%$

Second Sum

Grassy Eucalyptus Woodland

$<5$
$<5$
rare
rare
45
20
10
5
3
rare
2
$<1$
$<1$
rare
rare

$$
0.5
$$

0.5

0.5

0.5

0.5

1.0

0.5$$
23.0
$$$$
4.5
$$

Marsh

$\begin{array}{ccc} & 26.0 & \text { excl. } \\ & - & - \\ \text { CYPERACEAE } & - & \text { exc1. } \\ & 19.0 & \text { excl. } \\ & 2.0 & 3.0 \\ & 18.5 & 26.0 \\ & 2.0 & \text { excl. } \\ \text { CYPERACEAE } & - & \text { exc1. } \\ & - & \text { exc } 1 . \\ & - & \text { excl. } \\ & & \\ & 13.0 & 30.0 \\ & - & 1.0 \\ & 0.5 & 1.0 \\ & 0.5 & 0.5 \\ & 16.0 & 34.5 \\ & - & 1.0 \\ & 2.0 & 2.5\end{array}$


Compositae pollen again grossly overrepresent their importance in the vegetation of the area. However, the ratios of Eucalyptus/Gramineae plus Compositae in the soil surface and in the marsh samples are 0.29 and 0.5 respectively which can be used as guideline values for the modern grassy woodlands even though the Gramineae and Compositae values may be somewhat high as a result of species introduction and agriculture in the area.

\section{Fossil Pollen}

Pollen of arboreal taxa rarely exceeds ten per cent in the first sum and twenty per cent in the second sum. The tree pollen consist of a local component of Eucalyptus and Casuarina and a windborne component of $P$. aspleniifolius, Phaerosphaera hookeriana, Nothofagus cunninghamii and Podocarpus Zawrencii most of which has been transported from the western part of the Central Plateau and western Tasmania. Most of the pollen (89-90\%) of both sums is derived from local herbs, shrubs and aquatic plants with Gramineae, Compositae, Chenopodiaceae and MyriophyZZum types being predominant.

Ratios of Eucalyptus to Gramineae plus Compositae and of Eucalyptus to the windpollinated tree taxa have been calculated from the second sum data and graphed as a means of judging the relative importance of trees to herbaceous plants in the local vegetation, and the input of extraneous tree pollen components to the site. Although some of the Casuarina may be local its covariance with $P$. aspleniifolius and $P$. hookeriana suggests a more distant source for most of the input.

No pollen was recorded in the sediments below $0.75 \mathrm{~m}$ depth. At least the surface $0.1 \mathrm{~m}$ (possibly 0.2 ) of the core have been destroyed either by oxidation of organic matter consequent upon draining and ploughing of the lagoon floor or by mechanical compaction and removal of surface material.

The pollen diagram is divided into three zones on the basis of broad changes in the relative pollen frequencies.

zone $1(0.85-1.7+\mathrm{m})$ is characterised by relatively high values for Eucalyptus $(6-16.5 \%)$ and windborne pollen of the tree taxa Casuarina (3-12\%), and $P$. aspleni ifolius $(3-23 \%)$, the shrub $P$. hookeriana $(0-6.5 \%)$, and by relatively low values of Gramineae (5.5-29\%) (second sum). Myriophyzzum is very abundant (76.5-92.5\%).

Zone 2 (0.3-0.8 m) is characterised by low values of Eucalyptus (2-6.5\%) and wind transported pollen of Casuarina $(0-2.5 \%), P$. aspleniifolius $(0-10 \%)$ and $P$. hookeriana $(0-4 \%)$, and by a strong rise in pollen of Granineae (28-52.5\%) and Chenopodiaceae (11.5-31\%). Myriophizlzum is greatly reduced (2.5-17.5\%).

Zone $3(0-0.3 \mathrm{~m})$ is characterised by a sharp increase in Eucalyptus (16-17\%) with some accompanying increase in consistence of presence of Casuarina (1-1.5\%) and P. aspleniifolius ( $3.5 \%$ ), and by a marked decrease in pollen of Gramineae $23 \%$. pollen of Myriophyzlum (14\%) and Cyperaceae (11-18\%) increases during this zone.

The high values of Myriophyzlum in Zone 1 indicate that a shallow lake surrounded at least in part by abundant rooted aquatic plants was present during this period. The relatively high values of wind-pollinated tree taxa suggest that much of the tree pollen was transported into the area which probably had a grassy woodland to open-forest vegetation not markedly dissimilar from the present vegetation, but perhaps with fewer eucalypts as suggested by the ratio to wind-pollinated AP. It is difficult to assess the composition of the herb flora except to indicate that grass was probably more important than the curves of Compositae and Chenopodiaceae would suggest, as the modern samples point to grass being underrepresented and Compositae being grossly overrepresented.

The association of a gross reduction in Myriophyzlum with very strong increases in Gramineae, Compositae and Chenopodiaceae low in zone 2, where pollen of distant trees and local Eucalyptus was markedly reduced, points strongly to the development of a 
Pollen Diagram from Crown Lagoon, Tasmania

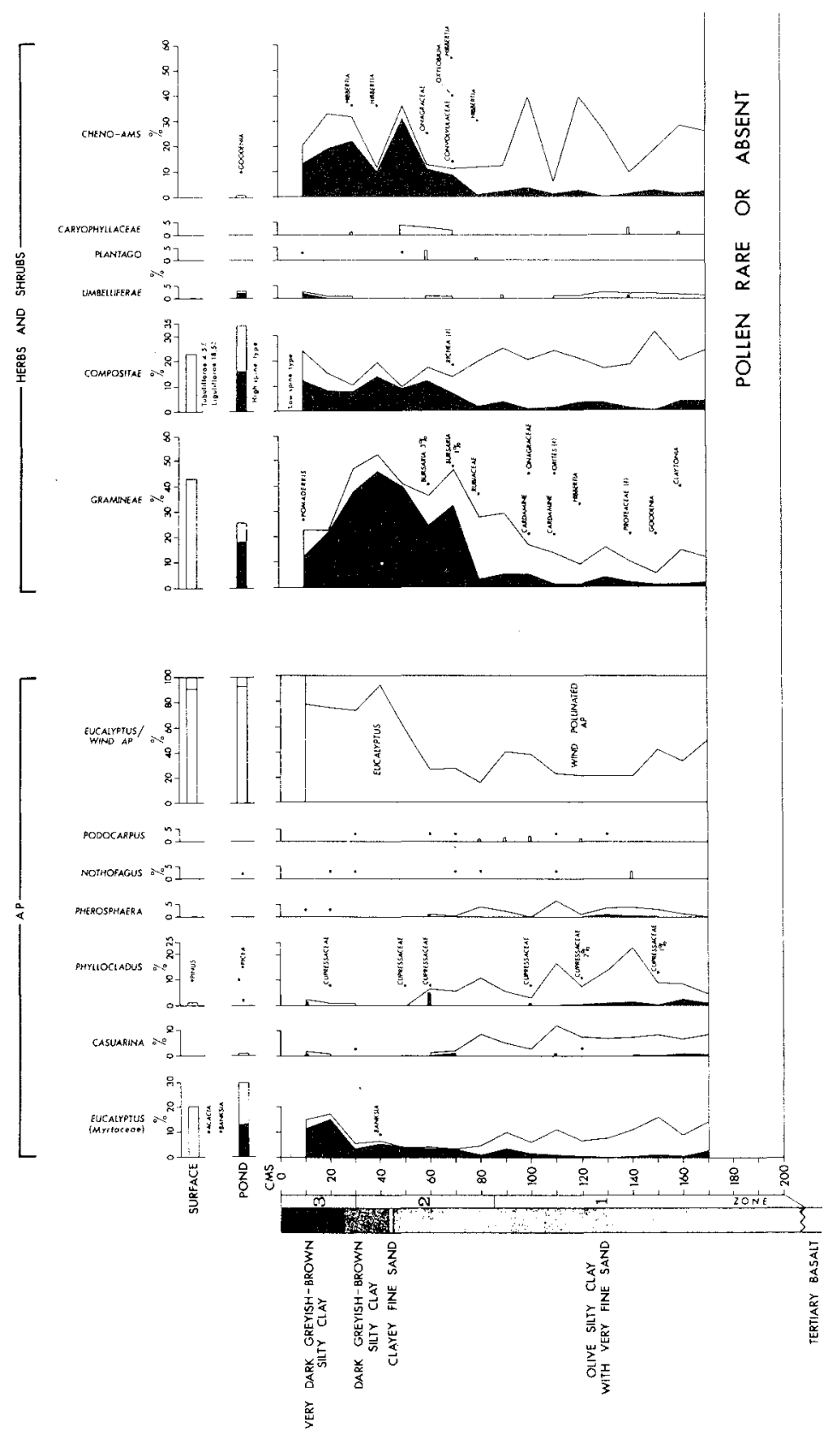

FIG. 3A - Part of pollen diagram. 


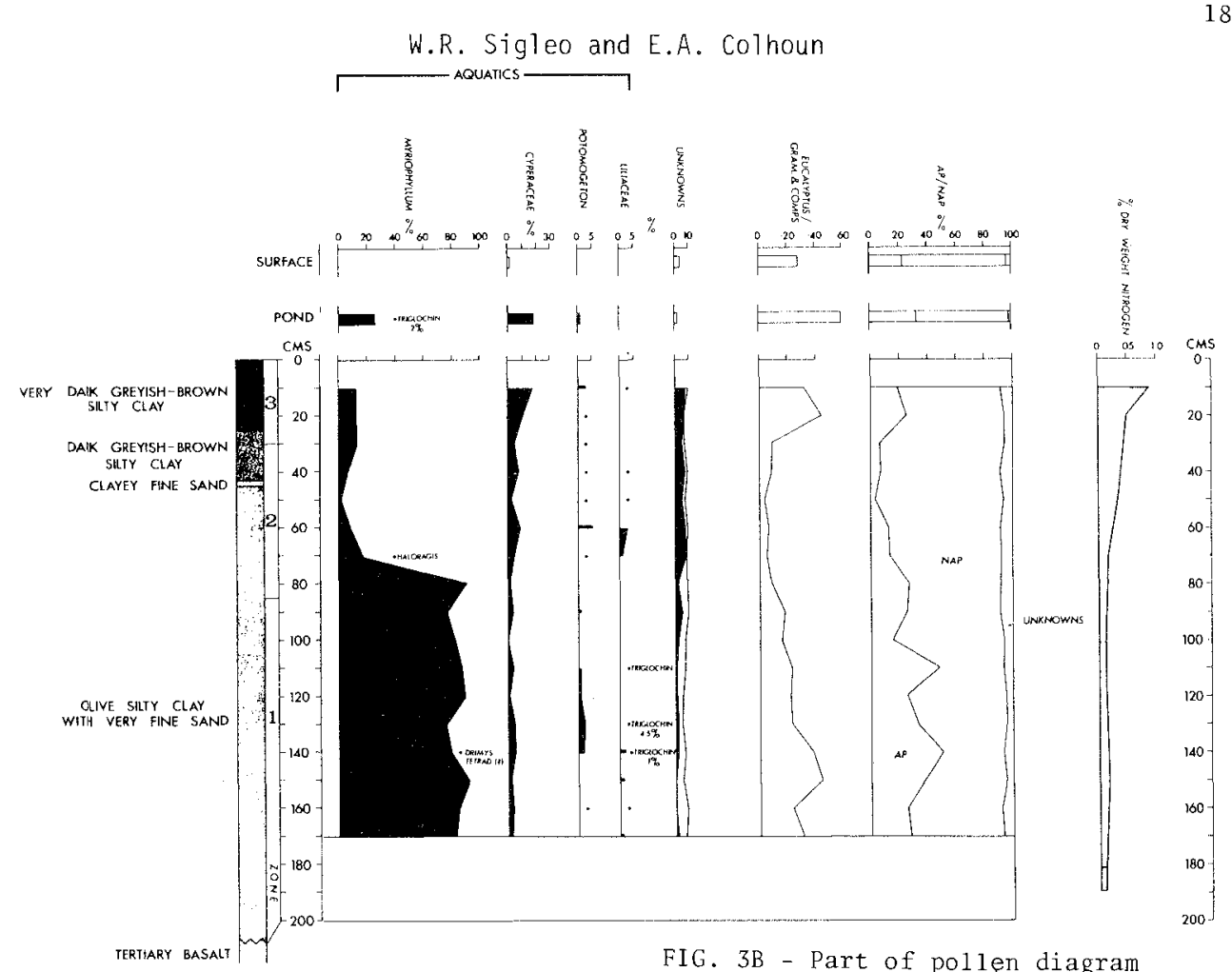

predominantly grassland environment with few trees present. During this period the lagoon probably dried out seasonally sufficiently often not to favour the maintenance of significant quantities of aquatic plants. This suggests that the climate associated with the vegetation of Zone 2 was markedly drier, at least during the summer season than that associated with the vegetation of Zone 1 in which eucalypts and aquatics were more abundant.

During zone 3 the marked increase in Cyperaceae and nitrogen levels may partly be related to infilling of the lake by organic materials. However, there is both a significant increase in Eucalyptus pollen almost to its modern level and a marked decrease of Gramineae also almost to its modern level of deposition in a pond environment. This suggests that zone 3 represents part of the Holocene vegetation of the area which was grassy woodland and grassy open-forest in a subhumid environment not dissimilar from the present one. It should be noted that the sharp rise in Eucaluptus at the base of Zone 3 does not coincide with the main lithological boundary at $0.45 \mathrm{~m}$, taken to be the approximate Pleistocene-Holocene boundary but occurs at the next lithological boundary at $0.25 \mathrm{~m}$. As it has not been possible to obtain ${ }^{14} \mathrm{C}$ assays on either boundary it is difficult to ascertain the time difference that may be involved between the slight increase in organic content of the sediments and the rise in Eucalyptus, or its significance. However, a gradual return to more wooded conditions is implied by the steep decrease in the curve for Gramineae between 0.4 and $0.3 \mathrm{~m}$ and by the marked increase in Eucaluptus above $0.25 \mathrm{~m}$.

From a consideration of the terrestrial and aquatic pollen taxa recorded it may be concluded that during the Late Pleistocene and Holocene at Crown Lagoon the vegetation varied from a grassy woodland through grassland (perhaps steppe) to grassy woodland or grassy open forest with more Eucalyptus being present during the Holocene than at any time previously. The vegetation suggests that the climate would have varied from being slightly drier and presumably cooler than at present with permanent water in the lagoon indicating a lack of extreme seasonal differences, through a phase of increased dryness probably 
related to reduced temperatures but with marked seasonal differences that caused regular drying out of the lagoon, to approximately the present subhumid climate.

\section{ACKNOWLEDGEMENTS}

The authors wish to thank the University of Tasmania and the Commonwealth Department of Education for financial support for this work. They also thank the Tasmanian Department of Mines for assisting with drilling and seismic work.

\section{REFERENCES}

Adam, D.P., 1967: Late Pleistocene and Recent palynology in the central Sierra Nevada, California. In:Cushing, E.I. and Wright, H.E. (Eds) : QUATERNARY PALAEOECOLOGY, Yale univ. Press: 275-301.

Curtis, W.M., 1963, 1967: THE STUDENT'S FLORA OF TASMANIA. Vols. 2 and 3, Govt, Printer, Hobart.

and Morris, D.I., 1975: THE STUDENT'S FLORA OF TASMANIA. Vol.1, 2nd edn., Govt. Printer, Hobart.

Kirkpatrick, J.B., 1981: A transect study of forests and woodlands on dolerite in the Eastern Tiers, Tasmania. Vegetatio, 39 (in press).

Mehringer, P.J., 1967: Pollen analysis of the Tule Springs area, Nevada. In

Wormington, $\mathrm{H}$. and Ellis, D. (Eds) PLEISTOCENE STUDIES IN SOUTHERN NEVADA: Nevada State Museum, Anthropological Papers, No.13: 130-200.

Sigleo, W.R., 1979: A STUDY OF LATE OUATERNARY ENVIRONMENT AND MAN FROM FOUR SITES IN SOUTHEASTERN TASMANIA. University of Tasmania, Ph.D. Thesis, $297 \mathrm{pp}$.

and Colhoun, E.A., 1981: Terrestrial dunes, Man and Late quaternary Enviroment in southern Tasmania. Palaeogeography, Palaeoecology and Pazaeoclimatology (submitted).

Specht, R.L., 1970: Vegetation. In G.W. Leeper (Ed.): THE AUSTRALIAN ENVIRONMENT, 4th edn., C.S.I.R.O. and Melb. Univ. Press: 44-67. 